\title{
Stability for Grain Yield and Other Traits in Tropical Maize (Zea mays L.) under Heat Stress and Optimal Conditions
}

\author{
K.A. Archana ${ }^{1}$, P.H. Kuchanur ${ }^{1 *}$, P.H. Zaidi ${ }^{2}$, S.S. Mandal ${ }^{3}$, B. Arunkumar ${ }^{1}$, \\ Ayyanagouda Patil ${ }^{4}$, K. Seetharam ${ }^{2}$ and M.T. Vinayan ${ }^{2}$ \\ ${ }^{1}$ Department of Genetics and plant breeding, University of Agricultural Sciences, \\ Raichur-584 104, Karnataka, India \\ ${ }^{2}$ International Maize and Wheat Improvement Center (CIMMYT) - Asia c/o ICRISAT, \\ Patancheru-502324, India \\ ${ }^{3}$ Department of Genetics and Plant Breeding, Bihar Agricultural University, Sabour, \\ Bhagalpur-813 210, Bihar, India \\ ${ }^{4}$ Department of Molecular Biology and Agriculture Biotechnology, University of Agricultural \\ Sciences, Raichur-584 104, Karnataka, India \\ *Corresponding author
}

\begin{tabular}{|c|c|}
\hline & A B S T R A C T \\
\hline & \multirow{5}{*}{$\begin{array}{l}\text { Twenty four newly developed maize hybrids along with three commercial checks were } \\
\text { evaluated for their yield performance at three locations under heat stress and optimal } \\
\text { conditions. Pooled analysis of variance revealed significant differences among hybrids for } \\
\text { grain yield. Mean sum of squares due to environments and linear component of } \\
\text { environments were significant for all the traits studied. Whereas, mean sum of squares due } \\
\text { to hybrids } \times \text { environment interactions and linear component of hybrids } \times \text { environment } \\
\text { interaction were significant only for grain yield indicating the diversity among the selected } \\
\text { environments. Based on the stability parameters, the hybrids, VL } 107 \times \text { VL128 }(0.97) \text { and } \\
\text { ZL } 1110175 \times \text { VL } 1033 \text { for days to } 50 \% \text { anthesis, ZL } 14501 \times \text { VL } 1032 \text { for days to } 50 \% \\
\text { silking, VL } 1011 \times \text { VL } 1033 \text { for anthesis silking interval and ZL } 11953 \times \text { VL } 1032 \text { for } \\
\text { grain yield were identified as stable as they recorded regression value nearer to unity and } \\
\text { non-significant deviation from regression. }\end{array}$} \\
\hline & \\
\hline $\begin{array}{l}\text { Grain yield, Tropical } \\
\text { maize (Zea mays L.), } \\
\text { Optimal conditions }\end{array}$ & \\
\hline Article Info & \\
\hline $\begin{array}{l}\text { Accepted: } \\
\text { 07 October } 2018 \\
\text { Available Online: } \\
\text { 10 November } 2018\end{array}$ & \\
\hline
\end{tabular}

\section{Introduction}

Maize (Zea mays L.) is one of the important cereal crops in the world and India next to wheat and rice and is known as queen of cereals because of its high yield potential among the cereals. Maize is grown in an area of $8.69 \mathrm{~m}$ ha with a production of $21.80 \mathrm{~m} \mathrm{t}$ and an average productivity $2.51 \mathrm{t} \mathrm{ha}^{-1}$ in
India. Karnataka is the one of important maize growing state in the country having a total area of $1.18 \mathrm{~m}$ ha with a production of $3.27 \mathrm{~m}$ $\mathrm{t}$ and an average productivity of $2.77 \mathrm{t} \mathrm{ha}^{-1}$ (Anonymous, 2016).

Maize grain is used mainly as feed for poultry, swine and fish (52 percent) and for cattle about 11 percent. About 23 percent used as a 
food and about 13 percent as an industrial raw material (Yadav et al., 2014). In addition to staple food for human being and quality feed for animals, maize serves as a basic raw material as an ingredient to thousands of industrial products that includes starch, oil, protein, alcoholic beverages, food sweeteners, pharmaceutical, cosmetic, film, textile, gum, package and paper industries etc.

Though maize is called queen of cereals, yet it encounters both abiotic and biotic stresses during its cultivation. Further, maize production and productivity are prone to rapid and constant changes due to global warming related environmental changes (Porter, 2005; Wahid et al., 2007). Heat stress is often defined as the rise in temperature beyond a threshold level for a period of time sufficient to cause irreversible damage to plant growth and development (Wahid et al., 2007). Heat stress for maize crop can be defined as temperature beyond a threshold level (Max temperature $>35^{\circ} \mathrm{C}$ and minimum temperature $>23^{\circ} \mathrm{C}$ ). Rise in temperature by one degree each day above $30^{\circ} \mathrm{C}$ was seen to lower final yield of maize in optimum and drought conditions by $1 \%$ and $1.7 \%$, respectively (Lobell et al., 2011). Further, increase in air temperature by $4-5^{\circ} \mathrm{C}$ during the kernel development leads to 73 per cent decrease in kernel number per ear (Carcova and Otegui, 2001).

The main effects of progressive heat stress on maize production are associated with reduced growth duration, reduced light interception and reproductive failure. The reproductive phase is the most sensitive growth stage to heat stress. High temperatures during flowering reduce the quantity and viability of pollen produced resulting in reduced fertilization of ovules, thereby reducing the sink capacity (Lobell et al., 2011). Kiniry and Ritchie (1985) reported high temperature could also cause kernel abortion, especially 10 days after pollination, as abortion commences early in kernel development before 12 days after pollination, at about the same period normal kernels undergo endosperm cell division and kernel enlargement begins. Cairns et al., (2013) reported that rise in temperature by $2^{\circ} \mathrm{C}$ would lower maize yield by $13 \%$ while, a $20 \%$ variation in intraseasonal rainfall would lower maize yields by $4.2 \%$ only.

Development of maize hybrids with stable performance in diverse environments is a challenge and there is a need to develop / identify hybrids that perform stably under various environmental conditions including heat stress. However, there are limited breeding efforts on heat stress tolerance in tropical maize in India especially, on stability of hybrids under heat stress and optimal conditions. Angadi (2014) identified four inbreds and five hybrids tolerant to heat stress. Krishnaji et al., (2017) and Dinesh et al., (2016) reported non-additive gene action for various traits under heat stress conditions. Therefore, the present investigation was carried out with the objective of identifying stable maize hybrids under heat stress and optimal conditions.

\section{Materials and Methods}

The experimental material consisted of 24 single cross hybrids developed by crossing eight inbreds as females and three testers as males (Table 1) in NCD-II design and three checks viz., 31Y45, D2244 and DKC 9108. The parents were selected based on their performance under heat stress and were either tolerant or moderately tolerant to heat stress. The hybrids were evaluated in alpha lattice design with two replications. Each hybrids was sown in two rows with a row length of 3 meters and spacing of $60 \mathrm{~cm} \times 20 \mathrm{~cm}$ at three locations viz., Agriculture College Faram, Bheemarayanagudi, Karnataka $\left(16^{\circ} 44^{\prime} \mathrm{N}\right.$ 
latitude, $76^{\circ} 47^{\prime} \mathrm{E}$ longitude and altitude of $458 \mathrm{~m}$ above mean sea level), CIMMYT (Asia), ICRISAT campus, Hyderabad, Telengana $\left(17^{\circ} 53^{\prime} \mathrm{N}\right.$ latitude, $78^{\circ} 27^{\prime} \mathrm{E}$ longitude and altitude of $545 \mathrm{~m}$ above mean sea level) and Bihar Agricultural University, Sabour, Bhagalpur, Bihar ( $25^{\circ} 15^{\prime} \mathrm{N}$ latitude, $87^{\circ} 2^{\prime}$ E longitude and altitude of $46 \mathrm{~m}$ above mean sea level). At Bheemarayanagudi and Hyderabad, the experiments were conducted during summer (March- June) 2016. Whereas, at Sabour, Bhagalpur, the experiment was sown during early spring (February -June) and the crop did not experience any stress (and considered optimal conditions). Recommended agronomic practices were followed for raising a good and healthy crop at all the locations. The observation were recorded on following characters viz., days to $50 \%$ anthesis, days to $50 \%$ silking, anthesis to silking interval, plant height and cob height on five randomly selected plants from each entry from the two replications.

While and grain yield was recorded on plot basis and expressed in $\mathrm{t} \mathrm{ha}^{-1}$. The weather parameters recorded at Bheemarayanagudi and Hyderabad indicated that the experiments were under heat stress as the $T_{\max }$ and $T_{\text {min }}$ recorded were above the values prescribed for the optimal growth of maize (Table 2). The stability parameters for grain yield and its component traits were worked out as suggested by Eberhart and Russell (1966) by using WINDOWSTAT 9.2 software.

\section{Results and Discussion}

In any breeding programme, it is necessary to screen and identify phenotypically stable hybrids, which could perform more or less uniformly under different environmental conditions. Considering this fact in mind, the present investigation was carried out to identify stable maize hybrids under heat stress and optimal environmental conditions.
Pooled analysis of variance (Table 3) revealed significant differences among hybrids for grain yield. Mean sum of squares due to environments and linear component of environments were significant for all the traits studied. Similarly, Adu et al., (2013) reported significant genotype and environment effects for grain yield in maize under heat stress. The mean sum of squares due to hybrids $x$ environment interactions and linear component of hybrids $\times$ environment interaction was significant only for grain yield indicating the diversity among the selected environments for the present investigation. Earlier, Hassan and Badreldin (1995) reported significant cultivar $\times$ environment interaction for grains/ear, grain weight and yield and significant environment (linear) effect was for all characters. Abera et al., (2004) reported significant year $\times$ location effects for all the traits using different stability models. Significant differences for grain yield, days to silking, days to anthesis and anthesis-silking interval were reported by Kamutando et al., (2013) among genotypes, environments and genotype $\times$ environment interactions (GEI).

The magnitude of non-linear component (pooled deviation) was greater than the linear component (hybrid $\times$ environment interaction) thus, indicating the difficulty in predicting the actual performance of genotypes across the environments for selected traits under heat stress and optimal conditions. Hence, prediction of performance of hybrids based on stability parameters would be feasible and reliable.

Eberhart and Russell (1966) defined stability as the ability of a hybrid to show a minimum interaction with the environment in which it is being grown. Stability of hybrids is often interlinked with significant hybrid $x$ environment interaction. A hybrid is considered to be more adaptive / stable one, if it has high mean yield but a low degree of 
fluctuation in yielding ability when grown over diverse environments. A stable hybrid is one which has above average mean yield, a regression coefficient of unity $(\mathrm{bi}=1)$ and non-significant mean square for deviations from regression $\left(S^{2} \mathrm{di}=0\right)$. High value of regression ( $\mathrm{bi}>1$ ) indicates that the hybrid is more responsive for input rich environment, while, low regression value $(\mathrm{bi}<1)$ is an indication of a hybrid adapted to poor environment. The phenotypic stability of hybrids was estimated by mean performance over locations, the regression coefficient (bi) and deviation from regression. Based on stability parameters, the hybrids viz., VL 107 $\times$ VL $128(0.97)$ and VL $062609 \times$ VL 1033 (1.05) exhibited regression value nearer to unity and non-significant deviation from regression, indicating their higher stability and wider adaptability across the environments for days to $50 \%$ anthesis, but with respect to the mean performance, these hybrids recorded little longer duration (data not shown). Earlier, Selvarajeswari (2016) also reported stable hybrids for days to 50 per cent taselling across locations in maize.

Table.1 List of parental lines used for crossing and their reaction to heat stress

\begin{tabular}{|c|c|c|c|c|}
\hline $\begin{array}{l}\text { SI. } \\
\text { No. }\end{array}$ & Line/Tester & Name & Source & $\begin{array}{l}\text { Reaction to } \\
\text { heat stress }\end{array}$ \\
\hline 1 & L1 & ZL14501 & $\begin{array}{l}\text { CIMMYT-Asia, } \\
\text { Hyderabad }\end{array}$ & $\mathrm{T}$ \\
\hline 2 & L2 & ZL11959 & $\begin{array}{l}\text { CIMMYT-Asia, } \\
\text { Hyderabad }\end{array}$ & $\mathrm{T}$ \\
\hline 3 & L3 & VL1110175 & $\begin{array}{l}\text { CIMMYT-Asia, } \\
\text { Hyderabad }\end{array}$ & MT \\
\hline 4 & L4 & ZL132102 & $\begin{array}{l}\text { CIMMYT-Asia, } \\
\text { Hyderabad }\end{array}$ & $\mathrm{T}$ \\
\hline 5 & L5 & VL062609 & $\begin{array}{l}\text { CIMMYT-Asia, } \\
\text { Hyderabad }\end{array}$ & $\mathrm{T}$ \\
\hline 6 & L6 & VL1011 & $\begin{array}{l}\text { CIMMYT-Asia, } \\
\text { Hyderabad }\end{array}$ & $\mathrm{T}$ \\
\hline 7 & L7 & VL107 & $\begin{array}{l}\text { CIMMYT-Asia, } \\
\text { Hyderabad }\end{array}$ & $\mathrm{T}$ \\
\hline 8 & L8 & ZL11953 & $\begin{array}{l}\text { CIMMYT-Asia, } \\
\text { Hyderabad }\end{array}$ & $\mathrm{T}$ \\
\hline 9 & $\mathrm{~T} 1$ & VL1032 & $\begin{array}{l}\text { CIMMYT-Asia, } \\
\text { Hyderabad }\end{array}$ & $\mathrm{T}$ \\
\hline 10 & $\mathrm{~T} 2$ & VL1033 & $\begin{array}{l}\text { CIMMYT-Asia, } \\
\text { Hyderabad }\end{array}$ & $\mathrm{T}$ \\
\hline 11 & $\mathrm{~T} 3$ & VL128 & $\begin{array}{l}\text { CIMMYT-Asia, } \\
\text { Hyderabad }\end{array}$ & MT \\
\hline
\end{tabular}

T- Tolerant, MT- Moderately Tolerant 
Table.2 Meteorological data recorded during cropping period (2016) recorded

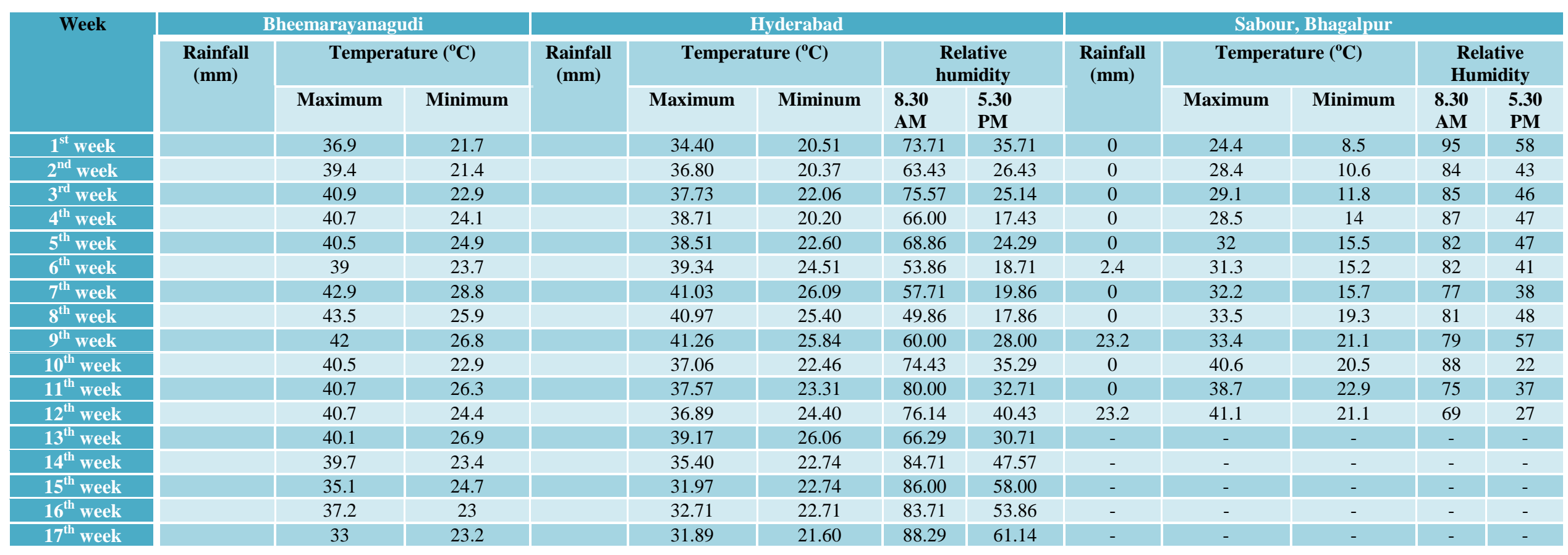

Table.3 Pooled ANOVA of stability for selected traits under heat stress and optimal conditions

\begin{tabular}{|c|c|c|c|c|c|c|c|}
\hline Source of Variation & df & $\begin{array}{l}\text { Days to } \\
50 \% \text { anthesis }\end{array}$ & $\begin{array}{c}\text { Days to } \\
50 \% \text { silking }\end{array}$ & $\begin{array}{l}\text { Antheis to silking } \\
\text { interval (d) }\end{array}$ & Plant height (cm) & Cob height (cm) & $\begin{array}{c}\text { Grain yield } \\
\left(\mathrm{t} \mathrm{ha}^{-1}\right)\end{array}$ \\
\hline Replications & 3 & 0.25 & 0.63 & 1.05 & 352.81 & 168.11 & $1.76^{*}$ \\
\hline Hybrids & 29 & 6.52 & 8.18 & 0.93 & 209.70 & 141.39 & $1.19 *$ \\
\hline Environments & 2 & $955.81 * *$ & $1143.86^{*}$ & $22.69 * *$ & $3518.31 *$ & $2872.23^{*}$ & $191.42 * *$ \\
\hline $\mathbf{G} \times \mathbf{E}$ interaction & 58 & 4.21 & 4.70 & 1.07 & 136.64 & 82.29 & $1.22 *$ \\
\hline Environment (linear) & 1 & $1911.62 * *$ & $2287.72 * *$ & $45.37 * *$ & $7036 . .62 * *$ & $5744.47 * *$ & $382.83 * *$ \\
\hline $\mathbf{G} \times \mathbf{E}$ interaction (Linear) & 29 & 2.91 & 3.82 & 0.59 & 46.95 & 41.41 & $1.82 * *$ \\
\hline Pooled deviation & 30 & $5.24 * *$ & $5.39 * *$ & $1.49 * *$ & $218.79 * *$ & $119.06^{* *}$ & $0.51 * *$ \\
\hline Pooled error & 87 & 1.96 & 2.61 & 0.68 & 122.69 & 40.27 & 0.19 \\
\hline Total & 89 & 26.35 & 31.43 & 1.51 & 236.44 & 164.24 & 5.48 \\
\hline
\end{tabular}

*Significance at $\mathrm{p}=0.05 * *$ Significance at $\mathrm{p}=0.01$ 
Table.4 Per se performance and stability parameters of hybrids for anthesis to silking interval (d) under Heat stress and optimal conditions

\begin{tabular}{|c|c|c|c|c|c|c|c|c|c|c|c|}
\hline \multirow{2}{*}{$\begin{array}{l}\text { SL } \\
\text { No }\end{array}$} & \multirow[t]{2}{*}{ Hybrid name } & \multicolumn{2}{|c|}{ Bheemarayanagudi } & \multicolumn{2}{|c|}{ Hyderabad } & \multicolumn{2}{|c|}{ Sabour } & \multicolumn{2}{|c|}{ Mean } & \multicolumn{2}{|c|}{ Stability Parameters } \\
\hline & & Days & Rank & Days & Rank & Days & Rank & Days & Rank & bi & $\mathbf{s}^{2} \mathrm{di}$ \\
\hline 1 & ZL14501 × VL1032 & 1.42 & 6 & 1.97 & 25 & 4.11 & 28 & 2.50 & 13 & 1.54 & 1.71 \\
\hline 2 & ZL14501 × VL1033 & 2.49 & 15 & 1.58 & 20 & 3.43 & 21 & 2.50 & 14 & 1.14 & -0.64 \\
\hline 3 & ZL14501 $\times$ VL128 & 2.58 & 18 & 1.55 & 18 & 3.38 & 20 & 2.50 & 15 & 0.57 & -0.68 \\
\hline 4 & ZL11959 × VL1032 & 2.17 & 10 & 1.47 & 16 & 3.36 & 19 & 2.33 & 10 & -0.05 & -0.53 \\
\hline 5 & ZL11959 × VL1033 & 2.47 & 13 & 0.68 & 2 & 2.35 & 1 & 1.83 & 5 & 1.24 & -0.36 \\
\hline 6 & ZL11959 × VL128 & 1.17 & 5 & 0.47 & 1 & 2.36 & 2 & 1.33 & 1 & -0.05 & -0.53 \\
\hline 7 & VL1110175 × VL1032 & 2.03 & 8 & 1.29 & 9 & 3.17 & 12 & 2.17 & 7 & 0.82 & -0.55 \\
\hline 8 & VL1110175 × VL1033 & 0.52 & 3 & 1.39 & 12 & 3.59 & 22 & 1.83 & 6 & 0.92 & 2.69 \\
\hline 9 & VL1110175 × VL128 & 2.90 & 19 & 2.12 & 27 & 3.99 & 27 & 3.00 & 25 & 1.70 & -0.58 \\
\hline$\overline{10}$ & ZL132102 × VL1032 & 2.03 & 9 & 1.29 & 11 & 3.17 & 13 & 2.17 & 8 & 0.82 & -0.55 \\
\hline 11 & ZL132102 × VL1033 & 3.56 & 24 & 1.65 & 21 & 3.29 & 17 & 2.83 & 21 & 0.67 & -0.21 \\
\hline 12 & ZL132102 × VL128 & 2.41 & 12 & 2.52 & 30 & 4.57 & 30 & 3.17 & 27 & 1.60 & 0.62 \\
\hline 13 & VL062609 × VL1032 & 2.35 & 11 & 1.41 & 14 & 3.25 & 15 & 2.33 & 11 & 2.01 & -0.65 \\
\hline 14 & VL062609 × VL1033 & 3.88 & 26 & 2.21 & 28 & 3.91 & 25 & 3.33 & 29 & 1.81 & -0.47 \\
\hline 15 & VL062609 × VL128 & 6.68 & 30 & 1.42 & 15 & 2.40 & 3 & 3.50 & 30 & -0.09 & 13.30 \\
\hline 16 & VL1011 × VL1032 & 2.49 & 16 & 2.04 & 26 & 3.97 & 26 & 2.83 & 22 & 1.08 & -0.29 \\
\hline 17 & VL1011 × VL1033 & 3.02 & 21 & 1.39 & 13 & 3.09 & 10 & 2.50 & 16 & 0.93 & -0.50 \\
\hline 18 & VL1011 × VL128 & 4.49 & 28 & 1.08 & 7 & 2.43 & 4 & 2.67 & 18 & 1.14 & 3.49 \\
\hline 19 & VL107× VL1032 & 3.96 & 27 & 1.73 & 22 & 3.31 & 18 & 3.00 & 26 & 1.29 & 0.27 \\
\hline 20 & VL107 × VL1033 & 3.59 & 25 & 0.95 & 3 & 2.46 & 5 & 2.33 & 12 & 0.47 & 1.14 \\
\hline 21 & VL107 × VL128 & 2.48 & 14 & 1.13 & 8 & 2.89 & 7 & 2.17 & 9 & 1.19 & -0.66 \\
\hline 22 & ZL11953 × VL1032 & 0.42 & 2 & 0.97 & 5 & 3.11 & 11 & 1.50 & 2 & 1.54 & 1.71 \\
\hline 23 & ZL11953 × VL1033 & 2.53 & 17 & 1.79 & 23 & 3.67 & 23 & 2.67 & 19 & 0.82 & -0.55 \\
\hline 24 & ZL11953 × VL128 & 1.09 & 4 & 0.95 & 4 & 2.96 & 8 & 1.67 & 4 & 0.46 & 0.15 \\
\hline 25 & 31Y45 (Check) & 0.16 & 1 & 1.07 & 6 & 3.28 & 16 & 1.50 & 3 & 0.04 & 2.81 \\
\hline 26 & D2244 (Check) & 1.87 & 7 & 2.26 & 29 & 4.37 & 29 & 2.83 & 24 & 1.85 & 1.28 \\
\hline 27 & DKC9108 (Check) & 5.08 & 29 & 1.55 & 19 & 2.88 & 6 & 3.17 & 28 & 0.58 & 3.97 \\
\hline & Mean & 2.63 & & 1.53 & & 3.25 & & \multirow{5}{*}{\multicolumn{4}{|c|}{ Grand mean $=2.47$}} \\
\hline & Environmental indices & -0.16 & & 0.94 & & -0.78 & & & & & \\
\hline & CV $(\%)$ & 63.70 & & 49.84 & & 25.35 & & & & & \\
\hline & CD (0.05) & 3.43 & & 1.56 & & 1.69 & & & & & \\
\hline & CD (0.01) & 4.62 & & 2.11 & & 2.27 & & & & & \\
\hline
\end{tabular}


Table.5 Per se performance and stability parameters of hybrids for grain yield $\left(\mathrm{t} \mathrm{ha}^{-1}\right)$ under heat stress and optimal conditions

\begin{tabular}{|c|c|c|c|c|c|c|c|c|c|c|c|}
\hline \multirow[t]{2}{*}{ Sl. No } & \multirow[t]{2}{*}{ Hybrid name } & \multicolumn{2}{|c|}{ Bheemarayanagudi } & \multicolumn{2}{|c|}{ Hyderabad } & \multicolumn{2}{|c|}{ Sabour } & \multicolumn{2}{|c|}{ Mean } & \multicolumn{2}{|c|}{ Stability Parameters } \\
\hline & & Yield & Rank & Yield & Rank & Yield & Rank & Yield & Rank & bi & $\mathrm{s}^{2} \mathrm{di}$ \\
\hline 1 & ZL14501 × VL1032 & 1.70 & 20 & 1.43 & 20 & 5.96 & 20 & 3.03 & 20 & 0.77 & -0.11 \\
\hline 2 & ZL14501 × VL1033 & 2.60 & 6 & 2.33 & 6 & 6.86 & 6 & 3.93 & 6 & 1.28 & 1.15 \\
\hline 3 & ZL14501 × VL128 & 1.21 & 29 & 0.94 & 29 & 5.47 & 29 & 2.54 & 29 & 0.73 & -0.04 \\
\hline 4 & ZL11959 × VL1032 & 2.22 & 14 & 1.95 & 14 & 6.48 & 14 & 3.55 & 14 & 1.17 & -0.24 \\
\hline 5 & ZL11959 × VL1033 & 1.27 & 25 & 1.00 & 25 & 5.53 & 25 & 2.60 & 25 & 0.91 & 0.10 \\
\hline 6 & ZL11959 × VL128 & 2.80 & 4 & 2.53 & 4 & 7.06 & 4 & 4.13 & 4 & 1.51 & 1.21 \\
\hline 7 & VL1110175 × VL1032 & 1.56 & 21 & 1.29 & 21 & 5.82 & 21 & 2.89 & 21 & 0.92 & 0.38 \\
\hline 8 & VL1110175 × VL1033 & 2.51 & 8 & 2.24 & 8 & 6.77 & 8 & 3.84 & 8 & 1.60 & 0.69 \\
\hline 9 & VL1110175 × VL128 & 2.03 & 19 & 1.76 & 19 & 6.29 & 19 & 3.36 & 19 & 1.17 & 0.27 \\
\hline 10 & ZL132102 × VL1032 & 1.24 & 26 & 0.97 & 26 & 5.50 & 26 & 2.57 & 26 & 0.43 & -0.24 \\
\hline 11 & ZL132102 × VL1033 & 0.91 & 30 & 0.64 & 30 & 5.17 & 30 & 2.24 & 30 & 0.41 & -0.22 \\
\hline 12 & ZL132102 × VL128 & 1.36 & 23 & 1.08 & 23 & 5.61 & 23 & 2.68 & 23 & 0.70 & -0.16 \\
\hline 13 & VL062609 × VL1032 & 2.35 & 12 & 2.08 & 11 & 6.61 & 11 & 3.68 & 11 & 0.69 & -0.04 \\
\hline 14 & VL062609 × VL1033 & 2.44 & 9 & 2.17 & 9 & 6.70 & 9 & 3.77 & 9 & 0.77 & 1.82 \\
\hline 15 & VL062609 × VL128 & 2.59 & 7 & 2.31 & 7 & 6.84 & 7 & 3.91 & 7 & 0.99 & 0.19 \\
\hline 16 & VL1011 × VL1032 & 2.93 & 2 & 2.66 & 2 & 7.19 & 2 & 4.26 & 2 & 1.43 & -0.18 \\
\hline 17 & VL1011 × VL1033 & 2.67 & 5 & 2.40 & 5 & 6.93 & 5 & 4.00 & 5 & 1.56 & -0.13 \\
\hline 18 & VL1011 × VL128 & 1.37 & 22 & 1.10 & 22 & 5.63 & 22 & 2.70 & 22 & 0.57 & 0.13 \\
\hline 19 & VL107× VL1032 & 2.11 & 15 & 1.84 & 15 & 6.37 & 15 & 3.44 & 15 & 1.15 & 0.43 \\
\hline 20 & VL107 × VL1033 & 2.41 & 10 & 2.13 & 10 & 6.66 & 10 & 3.74 & 10 & 1.02 & -0.23 \\
\hline 21 & VL107 × VL128 & 1.23 & 27 & 0.96 & 27 & 5.49 & 27 & 2.56 & 28 & 0.36 & 1.91 \\
\hline 22 & ZL11953 × VL1032 & 2.06 & 17 & 1.78 & 17 & 6.31 & 17 & 3.39 & 17 & 0.93 & -0.17 \\
\hline 23 & ZL11953 × VL1033 & 1.32 & 24 & 1.05 & 24 & 5.58 & 24 & 2.65 & 24 & 0.57 & -0.13 \\
\hline 24 & ZL11953 × VL128 & 2.05 & 18 & 1.77 & 18 & 6.30 & 18 & 3.37 & 15 & 1.14 & -0.19 \\
\hline 25 & 31Y45 (Check) & 2.27 & 13 & 1.99 & 13 & 6.52 & 13 & 3.60 & 13 & 1.40 & 0.50 \\
\hline 26 & D2244 (Check) & 2.89 & 3 & 2.62 & 3 & 7.15 & 3 & 4.22 & 3 & 1.14 & 2.19 \\
\hline 27 & DKC9108 (Check) & 3.19 & 1 & 2.92 & 1 & 7.45 & 1 & 4.52 & 1 & 1.56 & 1.47 \\
\hline & Mean & 2.12 & & 1.70 & & 6.27 & & \multirow{5}{*}{\multicolumn{4}{|c|}{ Grand mean $=3.36$}} \\
\hline & ironmental indices & 1.24 & & 1.66 & & -2.91 & & & & & \\
\hline & CV (\%) & 26.48 & & 18.48 & & 13.68 & & & & & \\
\hline & CD (0.05) & 1.15 & & 0.64 & & 1.75 & & & & & \\
\hline & CD (0.01) & 1.55 & & 0.86 & & 2.36 & & & & & \\
\hline
\end{tabular}


Hybrid, ZL $14501 \times$ VL 1032 recorded regression value equal to unity and nonsignificant deviation from regression $(-1.20)$, indicating its higher stability and wider adaptability across the environments for days to $50 \%$ silking. Another hybrid, ZL 1110175 $\times$ VL 128 also recorded regression value equal to unity and non-significant deviation from regression. But with respect to the mean performance, this hybrid recorded little longer duration (data not shown).

The mean performance of hybrids, VL $1011 \times$ VL 1033 and VL $1011 \times$ VL 1032 was 2.50 and 2.83 days for anthesis-silking interval, respectively (Table 4).

These hybrids recorded regression value of 0.93 and 1.08, respectively, and nonsignificant deviation from regression, indicating their stability and wider adaptability across the environments.

The hybrid, VL $1110175 \times$ VL 1032 was identified as a stable hybrid across environments as it recorded mean value of $59.33 \mathrm{~cm}$ for cob height under heat stress and optimal environmental conditions and regression value nearer to unity and nonsignificant deviation from regression (Table 5). On the same account, the hybrid VL 107 $\times$ VL 1033 was identified as a stable for grain yield. Syed et al., (2011); Balestre et al., (2009); Banik et al., (2010) reported stable maize cultivars across environments for grain yield.

From the present investigation, the hybrids, VL $1011 \times$ VL 1033 and VL $1011 \times$ VL 1032 and VL $107 \times \mathrm{VL} 1033$ were identified as stable for anthesis silking interval and for grain yield, respectively.

These hybrids need to be re-tested under various environments including heat stress conditions before their commercialization.

\section{References}

Abera, W., Van Rensburg, J. B. J., Labuschagne, M. T. and Maartens, H., 2004, Genotype-environment interactions and yield stability analysis of maize in Ethiopia. S. Afr. J. Plant Soil, 21(4): 251-254.

Adu, G. B., Akromah, R., Abdulai, M. S., Obeng-Antwi, K., Kena, A. W., Tengan, K.M.L. and Alidu, H., 2013, Assessment of genotype by environment interactions and grain yield performance of extra-early maize (Zea mays L.) hybrids. J. Bio. Agric. Healthcare, 3(12): 7-15.

Angadi, S., 2014, Evaluation of maize (Zea mays L.) inbred lines and hybrids for heat tolerance, M. Sc. (Agri.) Thesis, Univ. of Agric. Sciences, Raichur.

Anonymous, 2016, Annual Progress Report Kharif Maize, All India Coordinated Research Project on Maize. Indian Institute of Maize Research, PAU Campus, Ludhiana, India, pp. 1082.

Balestre, M., De Souza, J.C., Von Pinho, R.G., De Oliveira, R.L. and Valente Paes, J.M., 2009, Yield stability and adaptability of maize hybrids based on GGE biplot analysis characteristics. Crop Breed. App. Biotech., 9: 219-228.

Banik, B.R., Khaldun, A.B.M., Mondal, A.A., Islam, A. and Rohman, M.M., 2010, Assessment of Genotype-byenvironment interaction using Additive Main Effects and Multiplicative Interaction model (AMMI) in maize (Zea mays L.) hybrids. Acad. J. Plant Sci., 3(4): 134-139.

Cairns, J, E., Crossa, Zaidi, P. H., Grudloyma, P., Sanchez, C., Araus, J. L., Thaitad, S., Makumbi, Cheikh, J. and Jones, R. J., 2013, Disruption of maize kernel growth and development by heat stress. Plt. physiol., 106: 45-51. 
Carcova, J. and Otegui, M. E., 2001, Ear temperature and pollination timing effects on maize kernel set. Crop Sci., 41: 809-815.

Dinesh, A., Patil, A., Zaidi, P. H., Kuchanur, P.H., Vinayan, M. T. and Seethram, K., 2016 Line $\mathrm{x}$ testers analysis of tropical maize inbred lines under heat stress for grain yield and secondary traits. Maydica., 61: 135-139

Eberhart, S. A. and Russell, W. A., 1966, Stability parameters for comparing varieties. Crop Sci., 6: 36-40.

Hasssan lshag, M. and Badreldin Mohamed, A., 1995, Phasic development of spring wheat and stability of yield and its components in hot environments. Field Crops Research.46: 169-176.

Kamutando, C. N., Dean Muungani, Doreen Rudo Masvodza and Edmore Gasura, 2013, Exploiting genotype $\mathrm{x}$ environment interaction in maize breeding in Zimbabwe. African J. of Agril. Res. 8(11).

Krishnaji Jodage, Kuchanur, P. H., Zaidi, P. H., Ayyanagouda Patil, Seetharam, K., Vinayan, M. T., Arunkumar, B., 2017, Genetic Analysis of Heat Stress Tolerance and Association of Traits in Tropical Maize (Zea mays L.). Environment \& Ecology, 35 (3C): 23542360 .
Lobell, D. B., Banziger, M., Magorokosho, C. and Vivek, B., 2011, Nonlinear heat effects on African maize as evidenced by historical yield trials. Nature Clim. Change, 1: 42-45.

Selvarajeswari, N., 2016, Genotype $\times$ Environment interaction for grain yield and other quantitative traits in maize hybrids (Zea mays L.), M. Sc. (Agri.) Thesis, Univ. of Agric. Sciences, Bengaluru.

Syed Ijaz-Ul-Hassan, Muhammad Tariq and Noor-Ul-Islam, 2011, Performance Evaluation of Promising Yellow Maize Hybrids in Distinct Agro-Ecological Domains of Central Punjab, Pakistan. J. Agriculture \& Social Sci., 7 (4):143146

Wahid, A., Gelani, S., Ashraf, M. and Foolad, M. R., 2007, Heat tolerance in plants: An overview. Environ. and Experimental Botany, 61: 199-223

Yadav, O. P., Karjagi, C. G., Kumar B., Jat S. L., Chawla J. S., Kaul J., Hooda, K.S., Kumar, P., Yadava, P. and Dhillon B. S., 2014, Maize improvement in India, Abiotic stress-resilient Maize for adaptation to climate change in the asia. $12^{\text {th }}$ Asian Maize conference and consultation on maize for food, feed, nutrition and environmental security. pp 263-273

\section{How to cite this article:}

Archana, K.A., P.H. Kuchanur, P.H. Zaidi, S.S. Mandal, B. Arunkumar, Ayyanagouda Patil, K. Seetharam and Vinayan, M.T. 2018. Stability for Grain Yield and Other Traits in Tropical Maize (Zea mays L.) under Heat Stress and Optimal Conditions. Int.J.Curr.Microbiol.App.Sci. 7(11): 815-823. doi: https://doi.org/10.20546/ijcmas.2018.711.096 